\title{
Makna Kemah Suci Hingga Bait Allah Bagi Kehidupan Religius Kristen Masa Kini
}

\author{
Jhon Leonardo Presley Purba \\ Sekolah Tinggi Teologi Baptis Indonesia, Semarang \\ jhonpresley@stbi.ac.id
}

\begin{abstract}
:
The religious life of today's Christians cannot be separated from the religious life of God's people in Old Testament times centered on the Tabernacle and temple. Therefore, this study aims to find and explain the meaning of the Tabernacle and the Temple for today's Christian religious life. This research is presented in descriptive qualitative form. The method used is literature studies to collect as many theories as possible from literature materials that correlate with research topics. The sources used are textbooks, physical or e-books, and journals. The results of this study show the Tabernacle of God, through Moses, speaks of the image of Christ in His journey, ministry and glory on earth. While the Temple, through Solomon, spoke of Christ in His ministry and glory in heaven. Implementation for Christians today, everyone must come to God through faith in Christ, Christians are the temple or dwelling place of the Spirit of God today, God is always present and leads the christian life, Christians must offer themselves to God and be His witnesses in the world.
\end{abstract}

Keywords: christian; religious; tabernacle; temple

\begin{abstract}
Abstrak
Kehidupan religius orang Kristen masa kini tidak dapat dilepaskan dari kehidupan religius umat Allah pada zaman Perjanjian Lama yang berpusat pada Kemah Suci dan Bait Allah. Oleh karena itu, penelitian ini bertujuan untuk mencari dan menjelaskan makna Kemah Suci dan Bait Allah bagi kehidupan religius Kristen masa kini. Penelitian ini disajikan dalam bentuk kualitatif deskriptif. Metode yang digunakan adalah studi literature untuk mengumpulkan sebanyak mungkin teori dari bahan kepustakaan yang berkorelasi dengan topik penelitian. Sumbersumber yang digunakan adalah buku teks, fisik atau e-book, dan jurnal. Hasil penelitian ini menunjukan Kemah Suci Allah, melalui Musa, berbicara tentang gambaran Kristus dalam perjalanan, pelayanan dan kemuliaan-Nya di bumi. Sedangkan Bait Allah, melalui Salomo, berbicara tentang Kristus dalam pelayanan dan kemuliaan-Nya di surga. Implementasi bagi Kristen masa kini, setiap orang harus datang kepada Allah melalui iman dalam Kristus, orang Kristen adalah bait atau tempat berdiamnya Roh Allah saat ini, Allah senantiasa hadir dan menuntun kehidupan orang Kristen, orang Kristen harus mempersembahkan dirinya bagi Allah dan menjadi saksi-Nya di dunia.
\end{abstract}

Kata kunci: bait suci; kemah suci; kristen; religius

\section{Pendahuluan}

Kehidupan religius orang Kristen masa kini, secara historis tidak dapat dilepaskan dari awal mula sejarah lahirnya kekristenan itu sendiri pada masa Perjanian Baru. Pada awal berdirinya, kekristenan dianggap sebagai salah satu sekte dari Yudaisme yang pada saat itu belum memiliki sebutan khusus sebagai komunitas 
keagamaan (Flanders, Jr, Henry Jackson \& Cresson, 1973, p. 269). Dasar kepercayaan religius orang Kristen adalah beriman kepada Yesus dari Nazareth, seorang guru karismatik dan penyembuh dengan kuasa Ilahi, yang memberitakan akan kedatangan kerajaan Allah (Snyder, 2011) dan yang menyatakan diri sebagai Mesias yang telah dinubuatkan oleh kitab Taurat dan kitab nabi-nabi dalam PL (Luk. 24:27). Setelah beberapa waktu kemudian, orang-orang yang percaya kepada Yesus ini dikenal sebagai orang Kristen. Hal mendasar yang membedakan orang Kristen dengan orang Yahudi adalah pengakuan iman orang Kristen yang menyatakan Yesus sebagai Mesias, dalam konteks penggenapan dari nubuatan di kitab-kitab Taurat dan kitab nabi-nabi. Sebelum orang-orang Kristen ini memisahkan diri dari Yudaisme sebagai suatu komunitas keagamaan yang baru, sebagai orang Yahudi, orang-orang Kristen ini tetap melakukan peribadatan di Sinagoge-Sinagoge Yahudi dan Bait Allah. Orang-orang Kristen ini juga tetap melakukan persembahan-persembahan korban, doa-doa dan menghadiri perayaan-perayaan keagamaan Yahudi (Flanders, Jr, Henry Jackson \& Cresson, 1973, p. 383).

Dalam konteks sejarah Kekritenan di dalam Alkitab, sangat signifikan hubungan yang ada antara agama Patriark hingga Yudaisme dalam PL dengan agama Kristen dalam PB, khususnya pengaruh dan hubungan dalam pola peribadatan. Pada zaman kehidupan para Patriark, dilakukan pembangun altar atau mezbah untuk mempersembahkan korban bakaran kepada Allah. Dalam narasi kitab Kejadian dapat ditemukan bahwa pola peribadahan ini pertama kali dilakukan oleh Nuh setelah air bah surut, sebagai suatu bentuk ucapan syukur kepada Allah. Nuh melakukan ini secara spontan tanpa maksud untuk melakukan segala instruksi pola peribadahan yang kemudian diberikan oleh Allah kepada Musa (O'Collins, Gerald \& Keenan Jones, 2010, pp. 1-2). Setelah peristiwa Keluaran, Allah kemudian memerintahkan Musa untuk membuat Kemah Suci dan memilih salah satu dari 12 suku bangsa Israel yaitu suku Lewi, yang dipercaya dan diakui telah dipilih oleh Allah untuk memimpin ritual-ritual peribadahan (Mangean, 2019). Jika melihat dalam konteks unsur-unsur peribadatan, ada persamaan yang tampak pada pola ibadah keagamaan dari zaman Nuh hingga Musa yaitu: orang yang beribadah, ritual peribadatan dan tempat ibadah (Bowo, 2020). Jika membandingkan dengan masa penciptaan, dapat juga ditemukan hubungan yang paralel antara Kemah Suci dan Taman Eden dimana kontur, substansi dan makna Taman Eden menerangkan Kemah Suci dan segala pelayanan didalamnya, begitupun sebaliknya memahami Kemah Suci dapat membantu untuk memahami konsep Taman Eden (Hinckley, 2013).

Sangat penting untuk memahami bahwa mendirikan Kemah Suci merupakan peristiwa yang penting dalam peribadatan bangsa Israel selama di pengembaraan di padang gurun. Dalam Kitab Bilangan, Kemah Suci disebut sebagai Kemah Pertemuan karena fungsinya sebagai tahta Allah Yahweh yang kasat mata di bumi dan dalam Kemah Pertemuan inilah Allah dapat ditemui oleh Musa maupun imam besar (Joseph \& Joseph, 2020). Menurut Alkitab, Kemah Suci merupakan sebuah kuil tenda portabel dan berornamen, berfungsi sebagai rumah terestrial untuk Allah Israel kuno (Yahewh) mulai dari awal pembangunannya di Gunung Sinai di bawah pengawasan Musa hingga 
kemudian digantikan oleh Bait Allah Salomo (Homan, 2007). Fungsi utamanya adalah sebagai sentral peribadahan dengan menggunakan persembahan korban bakaran, dengan aturan-aturan tertentu bagi pemilik dan hewan korban yang akan dipersembahkan di Kemah Suci (Aloni \& אלוני \&, 1983). Pada masa pemerintahan Salomo, Kemah Suci kemudian diganti dengan Bait Allah sebagai tanda bahwa Allah telah memberikan istirahat kepada umat Allah dari pengembaraan di padang gurun (Joseph \& Joseph, 2020). Melalui Kemah Suci dan Bait Allah ini, Allah hadir ditengah-tengah umat Allah dan umat Allah beribadah kepada Allah. Menurut Gregory Beale Kemah Suci dan Bait Allah merupakan rancangan yang secara simbolis menggambarkan realitas di akhir zaman nanti ketika kehadiran Allah, yang sebelumnya hanya terbatas di Ruang Maha Kudus, akan memenuhi seluruh alam semesta (Beale, 2004).

Salomo membangun Bait Allah di Yerusalem, di puncak Gunung Moria, dan bait ini berfungsi sebagai Rumah Tuhan selama kurang lebih empat ratus tahun. Bait Allah yang dibangun oleh Salomo ini dikenal sebagai Bait Allah pertama. Pasukan Babilonia kemudian menghancurkan Bait Allah ini dalam invasi militer ke Yerusalem pada tahun 586 SM. Kemudian pada tahun 520 SM proyek pembangunan kembali Bait Allah dilakukan dibawah pengawasan Zerubbabel, yang dikenal sebagai Bait Allah kedua. Bangunan Bait Allah ini kemudian mengalami renovasi besar-besaran oleh Herodes pada tahun 20 SM. Bait Allah Herodes di Yerusalem ini akhirnya dihancurkan pada tahun 70 M oleh pasukan Romawi. Banyak peristiwa paling terkenal dalam Alkitab dan sejarah terjadi di sekitar Kemah Suci dan Bait Allah di Yerusalem, karena bangunan ini adalah bangunan terpenting dalam sejarah Israel kuno. Selama dua milenium terakhir, Kemah Suci maupun Bait Allah telah menjadi fokus yang lebih diperhatikan dari pada bangunan lain di zaman kuno (Homan, 2007). Bait Allah di Yerusalem juga dapat dikatakan adalah bangunan suci paling terkenal dalam sejarah dunia bersama tokohtokoh yang menonjol dalam tulisan-tulisan apokaliptik (Garber \& Parrot, 1958; Joseph \& Joseph, 2020).

Kekristenan PB lahir dan memiliki keterkaitan yang erat dengan agama Israel kuno PL. Implikasi dari hal ini adalah secara historis maupun teologis ritual-ritual keagamaan dan tempat-tempat pusat peribadatan bangsa Israel kuno, Kemah Suci dan Bait Allah, memiliki makna penting bagi kehidupan iman Kekristenan, baik Kekristenan kuno pada masa PB maupun Kekristenan modern pada masa kini. Berdasarkan pemikiran di atas, penelitian ini dimaksudkan untuk menemukan makna teologis dari Kemah Suci dan Bait Allah serta bagaimana makna teologis tersebut diimplementasikan bagi kehidupan kerohanian (religious) orang Kristen pada masa kini.

\section{Metode}

Penelitian ini disajikan dalam bentuk kualitatif deskriptif.(Zaluchu, 2020) Metode yang digunakan adalah studi litaratur untuk menjawab permasalahan penelitian dengan mencari dan mengumpulkan teori yang berkorelasi dengan topik penelitian melalui sumber-sumber literatur yaitu buku teks, baik buku fisik maupun e-books, dan jurnal. Analisis teori-teori yang diperoleh dalam penelitian ini diuraikan secara sistematis, 
singkat, dan menjadikan tujuan penelitian sebagai patokan deskripsi (Zaluchu, 2021). Pembahasan dalam peneltian diuraikan melalui sub-sub pembahasan. Pertama, uraian tentang Kemah Suci dan Bait Allah beserta makna teologis dari keduanya. Kedua, uraian tentang kehidupan kerohanian (religious) orang Kristen masa kini. Ketiga, uraian tentang implementasi makna teologis Kemah Suci dan Bait Allah bagi kehidupan kerohanian orang Kristen masa kini.

\section{Hasil dan Pembahasan \\ Kehidupan Rohani Israel}

Di zaman para Patriakh, praktik kerohanian atau keagamaan dilakukan dengan sederhana melalui pemujaan (cultus). Pemujaan yang dilakukan dapat dibagi kedalam dua kategori, pertama adalah perjanjian covenan dan pembaharuan janji-janji dalam covenan. Dalam hal ini termasuk praktik sunat yang memiliki hubungan dengan covenan sebagai tanda permanen akan ketaatan dari generasi-generasi yang akan mewarisi covenan tersebut. Kedua, mempersembahkan "persembahan" kepada Yahweh (Tuhan), praktik ini merujuk pada persembahan "perpuluhan" yang dilakukan Abraham dan Yakub (Flanders, Jr, Henry Jackson \& Cresson, 1973, p. 59).

Bangsa Israel, dipilih menjadi umat perjanjian oleh Yahweh (Tuhan) melalui Abraham. Israel dipiliha Tuhan sebagai alat-Nya untuk menyatakan diri-Nya dengan tujuan memulihkan hubungan yang telah hancur antara Tuhan dan manusia ciptaan-Nya (Hill, Andrew \& Walton, 2008, p. 111). Praktik kerohanian atau keagamaan pada zaman Israel kuno telah berkembang lebih kompleks dari zaman Patriakh, meskipun secara prinsip praktik yang dilakukan para Patriakh adalah dasar dari praktik yang dilakukan bangsa Israel. Penyembahan kepada Yahweh (Tuhan) di zaman Israel kuno dilakukan melalui seorang pemimpin rohani. Ada tiga pemimpin rohani yang utama bangsa Israel yaitu iman, nabi dan orang berhikmat. Dalam melakukan tugas kepemimpinan kerohanian, ketiganya tidak terpisah satu sama lain, tapi bekerjasama dan saling terhubung (Flanders, Jr, Henry Jackson \& Cresson, 1973, p. 125). Penyembahan dan persembahan kepada Tuhan melalui kepemimpinan para pemimpin rohani Israel kuno terpusat pada tempat khusus yang disebut Kemah Suci dan Bait Allah.

\section{Kemah Suci}

Kemah Suci atau Tabernakel menjadi tempat suci portabel orang Israel selama pengembaraan bangsa Israel di padang gurun. Kemah Suci ini adalah tenda, menyerupai tenda-kuil portabel yang digunakan oleh orang Semit kuno. Kemah Suci ini didirikan tepat ditengah-tengah tenda-tenda bangsa Israel sehingga Kemah Suci ini akan menjadi pusat dari perkemahan bangsa itu. Kemah Suci ini menjadi tempat penyimpanan Tabut Perjanjian (Joseph \& Joseph, 2020). Kemah Suci atau Tabernakel tidak hanya sebagai simbol dari penebusan tapi juga tempat Allah (Yahweh) berdiam diantara umat Allah. Musa membangun Kemah Suci ini berdasarkan pola yang diberikan kepadanya di gunung (Kel.25:40; Ibr.8:5) (Frey, n.d., p. 31). Kemah Suci memiliki tiga bagian utama. Setiap bagian berisi benda-benda sakral yang khusus. Setiap bagian juga merupakan 
tempat kegiatan sakral yang berbeda (Publishing, 2008, p. 35). Bagian pertama adalah halaman luar (courtyard). Benda suci: Halaman adalah akses utama ke Kemah Suci. Gerbang lebar adalah tempat orang Israel kuno akan membawa korban dan persembahan. Di sana, para imam akan menerima dan memberkati orang. Di dalam halaman, para imam akan mempersembahkan korban di altar perunggu. Ada juga bejana perunggu, di mana para imam dapat membersihkan diri menjadi bersih secara ritual (Publishing, 2008, p. 35).

Bagian kedua adalah Tempat Kudus (Holy Place) memiliki tiga benda penting untuk pelayanan Kemah Suci: Pelita emas, meja roti persembahan, dan mezbah dupa. Para imam melakukan tugas sehari-hari di dalam Tempat Kudus: para imam harus menjaga lampu tetap menyala, mempersembahkan dupa dua kali sehari, dan membawa roti segar setiap minggu ke meja persembahan (Publishing, 2008, p. 35). Bagian ketiga adalah Tempat Maha Kudus (The Most Holy Place) tempat ini merupakan tempat yang unik dan khusus untuk menyimpan Tabut Perjanjian. Hadirat Tuhan sendiri berdiam di Tempat Maha Kudus. Hanya Imam Besar yang dapat memasuki ruangan ini setahun sekali, dilindungi oleh kepulan asap dari dupa yang dibakar. Perayaan terpenting dalam kalender Yahudi, Hari Pendamaian, mencapai puncaknya di Tempat Maha Kudus, di mana imam besar mempersembahkan darah hewan kurban kepada Tuhan untuk menebus dosa orang-orang (Publishing, 2008, pp. 35-36).

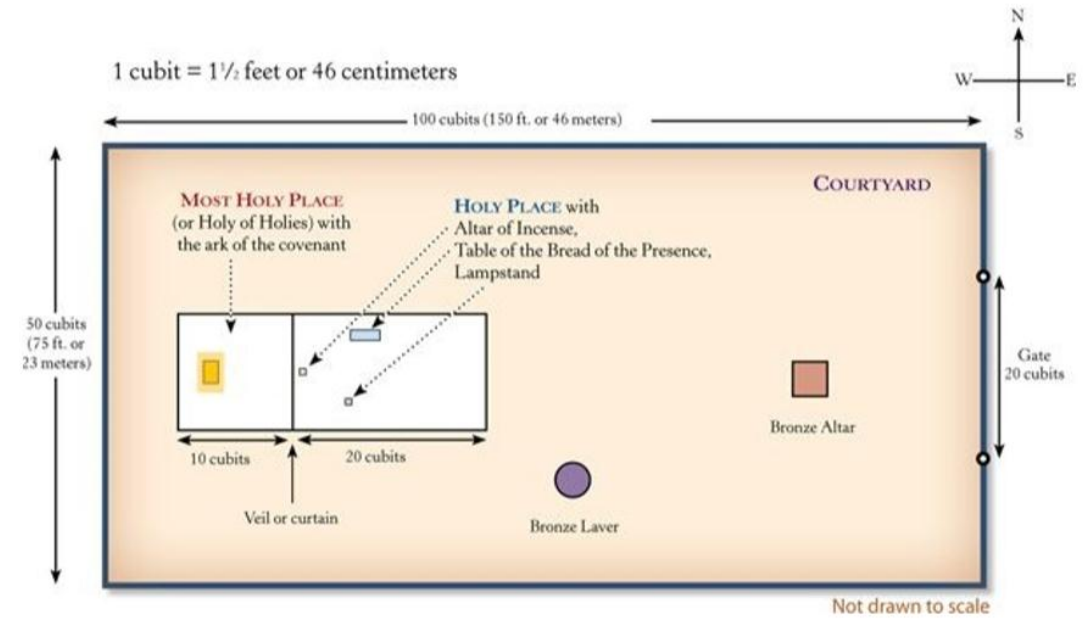

Gambar 1. Ilustrasi Kemah Suci (Publishing, 2008, p. 35).

Pesan terpenting yang disampaikan oleh hukum-hukum yang diberikan kepada bangsa Israel kuno adalah bahwa Tuhan itu kudus dan sebaliknya, manusia tercemar dan tidak layak, di dalam dan dari dirinya sendiri untuk mendekati Tuhan yang kudus. Semua ini, pada gilirannya berfungsi untuk menanamkan dalam pikiran orang Israel kuno kekudusan ruang Tabernakel / Kemah Suci dalam konsep "topografi kultus" yang dihasilkan oleh sistem yang bersih dan najis (Sprinkle, 2000).

\section{Bait Allah}

Bait Allah di Yerusalem dibangun oleh Salomo, putra Daud. Bait Allah Salomo

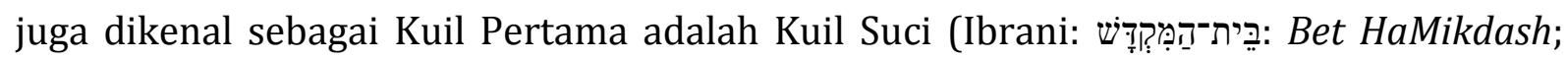


Arab: بيت المقدس: Beit al-Quds) di Yerusalem kuno, di gunung Bait Allah (Temple Mount) atau yang dikenal juga sebagai Gunung Zion (Bloch-Smith, 2020), yang juga dikenal sebagai tempat Akedah atau ikatan Abraham atas Ishak (Kejadian 22: 1-24) (Killebrew, 2015). Bait Allah ini sangat penting bagi bangsa Israel sebelum kehancuran Bait Allah ini terjadi oleh invasi Nebukadnezar II setelah pengepungan Yerusalem tahun 587 SM (Bloch-Smith, 2020). Masa pemerintahan Salomo sangat penting khususnya bagi pembangunan Bait Allah pertama ini yang menjadi tempat utama peribadatan agama orang Israel kuno, juga sebagai tempat untuk mengumpulkan dan menulis materi-materi keagamaan Yahweisme dan diselesaikannya "narasi Hukum Taurat dan kitab-kitab Ibrani" (Flanders, Jr, Henry Jackson \& Cresson, 1973, pp. 148-149).

Menurut tradisi Alkitab, menjadikan Yerusalem sebagai ibu kota dan pusat religius suku-suku Israel yang baru bersatu dalam satu pemerintahan berkaitan erat dengan Daud, raja pejuang besar yang menaklukkan pemukiman pedesaan di perbukitan yang dihuni oleh orang-orang Yebus (Killebrew, 2015). Daud adalah orang yang ingin membangun Bait Allah pada awalnya. Daud merasa tidak pantas jika Tuhan Allah belum memiliki 'rumah' yang layak bagi Tuhan, sedangkan Daud sendiri tinggal di dalam rumah dari kayu aras (2 Samuel 7:2; 1 Tawarikh 17:1). Daud juga pernah bernazar tidak mau tidur, "sampai aku mendapat tempat untuk TUHAN atau kediaman untuk Yang Mahakuasa dari Yakub” (Mazmur 132:2-5). Daud telah merencanakan dan mempersiapkan segalanya bagi pembangunan Bait Allah tersebut, seperti lokasi, bahanbahan untuk membangun, dana untuk membangun, tenaga untuk membangun, dan lainlain (2 Tawarikh 22:2-29), namun Daud tidak diizinkan oleh Tuhan untuk mendirikan Bait Suci Allah tersebut (Bowo, 2020).

Salomo, putra Daud yang kemudian membangun Bait Allah pertama untuk Yahweh di Gunung Moriah (Killebrew, 2015). Salomo melaksanakan apa yang menjadi tugasnya dengan membangun Bait Suci, seluruh kegiatan dan pusat penyembahan terpusat di Yerusalem (Arifianto \& Santo, 2020). Daud memohon kepada para pangeran Israel untuk membantu Salomo dalam pekerjaan yang akan datang, menyiapkan tempat permanen untuk Tabut Perjanjian dan bejana suci serta sakramen ritual leluhur bangsa Israel. Kemudian Daud menyampaikan kepada Salomo rencana yang telah diberikan Tuhan kepada Daud untuk pola Bait Allah dan struktur yang berdekatan, termasuk pengaturan fungsi klerikal dan bahkan bobot dari berbagai benda ritual dan perabotan Bait Suci (Wasserman, 2011, p. 164).

Allah adalah Arsitek dan Perancang dari Bait Suci Allah ini. Semua pola berdasarkan hikmat yang diberikan Allah kepada Daud (1 Tawarikh 28:11-19). Daud mendapat penglihatan tentang Rumah Tuhan. Daud menerima pola Ilahi kemudian menuliskan semua visi itu dan membuatnya dangan jelas sehingga Salomo dan para pekerja dapat membangun sesuai dengan pola yang Tuhan berikan (Conner, 1988, p. 23).

Ketika orang Babilonia mengalahkan orang Asyria dan Mesir dalam pertempuran Karkemis pada tahun 605 SM, pertempuran ini juga membuka jalan bagi orang Babilonia untuk langsung menyerbu Kerajaan Yehuda. Invasi pertama terjadi pada tahun 597 SM, 
di bawah raja Babilonia Nebukadnezar dan raja Yehuda Yoyakhin. Raja Babel Nebukadnezar membawa semua harta rumah Tuhan dan harta rumah raja, dan memotong-motong semua bejana emas di dalam Bait Allah, yang telah dibuat oleh Raja Israel yaitu Salomo, seperti yang Tuhan nubuatkan " (2 Raja 24: 12 - 13). Yoyakhin digantikan oleh Zedekia, paman dari Yoyakhin yang dilantik oleh raja Babilonia (2 Raja 24). Zedekia memberontak melawan pemerintahan Babilonia dan di tahun 587 / 586 SM Nebukadnezar kembali menyerbu dan menghancurkan Yerusalem sepenuhnya, membawa semua penghuninya ke pembuangan di Babilonia, sehingga orang Israel dijadikan sebagai tawanan (Arifianto, 2020a). Bait Allah pertama hancur total. Alkitab PL mencatat pembongkaran, pemecahan, dan pengangkutan artefak perunggu Bait Allah ke Babilonia, termasuk pilar, serta emas dan perak (Lundquist, 2008, pp. 42-43).

Orang-orang Israel yang kembali dari pembuangan dengan perasaan penuh kemenangan menjadi permulaan yang menandai pembangunan awal Bait Allah kedua bagi Yahweh dan pembangunan kembali secara bertahap sebagai pusat spiritualitas Yahudi (Killebrew, 2015). Pembangunan kembali Bait Allah di Yerusalem setelah periode panjang kehancuran dan penelantaran setelah 586 SM, terjadi melalui kemurahan hati dan inisiatif dari salah satu raja kuno terbesar yang paling tercerahkan yaitu Cyrus I, Raja Persia (memerintah 539 - 530 SM). Cyrus memasuki Babilonia dengan damai pada tahun 539 SM, setelah mengalahkan raja Babilonia terakhir, Nabonidus (memerintah 559 - 539 SM). Pembangunan Bait Allah kedua ini selesai "pada hari ketiga Adar, pada tahun keenam masa pemerintahan Darius sang raja" (Ezra 6: 15 = Maret - April [bulan kedua belas] 516 SM). Dari perspektif Alkitab Ibrani, tanggal ini penting sebagai penggenapan, dan melengkapi, nubuat tentang tujuh puluh tahun pengasingan, misalnya di Yeremia 25: 11 - 12 dan Yeremia 29: 10. Tujuh puluh tahun dihitung dari 586 SM, penghancuran Bait Allah Salomo oleh Nebukadnezar hingga 516 SM (Lundquist, 2008, p. 71).

Bangsa Israel sangat membanggakan Bait Allah kedua yang dibangun dengan sangat istimewa dan penuh perjuangan. Begitu penting kehadiran Bait Allah kedua ini di tengah-tengah umat Israel sebagai tempat pertemuan dengan Tuhan, sebagai tempat ibadah kepada Tuhan. Selanjutnya Bait Allah kedua inilah yang digunakan bangsa Israel untuk beribadah selama beberapa waktu (Bowo, 2020). Bait Allah kedua ini penting untuk mengingatkan bangsa Israel catatan dalam Kitab Keluaran, bahwa Tuhan berbicara kepada anak-anak Israel saat bangsa ini berdiri di depan Gunung Sinai dengan kata-kata, "Kamu akan menjadi bagi-Ku kerajaan imam dan bangsa yang kudus" (19: 6). Menurut Martha Himmelfarb kalimat ini bersifat paradok karena secara definisi imam adalah minoritas, namun makna dalam konteksnya jelas, ini untuk menyatakan bahwa seluruh umat Israel itu kudus (Loader, 2008).

Pada tahun 20 SM, Herodes mulai melakukan renovasi dan perluasan Bait Allah di Yerusalem. Herodes adalah raja di Yudea. Herodes menjadi raja setelah berhasil merebut Yerusalem dengan bantuan Romawi pada tahun 37 SM. Meskipun Herodes bukan orang Yahudi, namun keluarga Herodes merupakan penganut agama Yudaisme. Herodes memiliki ambisi dan rencana yang besar untuk menyenangkan seluruh 
pemilihnya, termasuk Yahudi tradisional, yang menurutnya merestorasi Bait Allah akan menjadi keinginan utama orang-orang Yahudi. Sebagaimana orang-orang Yahudi Helenistik yang lebih kosmopolitan, yang tinggal di kota-kota besar seperti Korintus, Antiokhia, dan Roma yang memiliki kuil-kuil besar di dunia Yunani dan Romawi, demikian juga harapan orang-orang Yahudi di Yerusalem untuk memiliki Bait Allah yang megah yang setara dengan kuil-kuil di dunia Yunani dan Romawi. Pada tahun kedelapan belas masa pemerintahannya (20 SM) Herodes menyampaikan pidato yang menyentuh hati orang-orang Yahudi yang berkumpul di Yerusalem dan kemudian mulai melaksanakan rencananya untuk perluasan total Bait Allah, namun perluasan Bait Allah ini belum selesai hingga kematian Herodes tahun 4 SM (Conner, 1988, p. 214).

Berikut ini gambar-bambar ilustrasi Bait Allah yang dibangun Salomo, Ezra dan Nehemia dan Bait Allah yang direnovasi oleh Herodes.

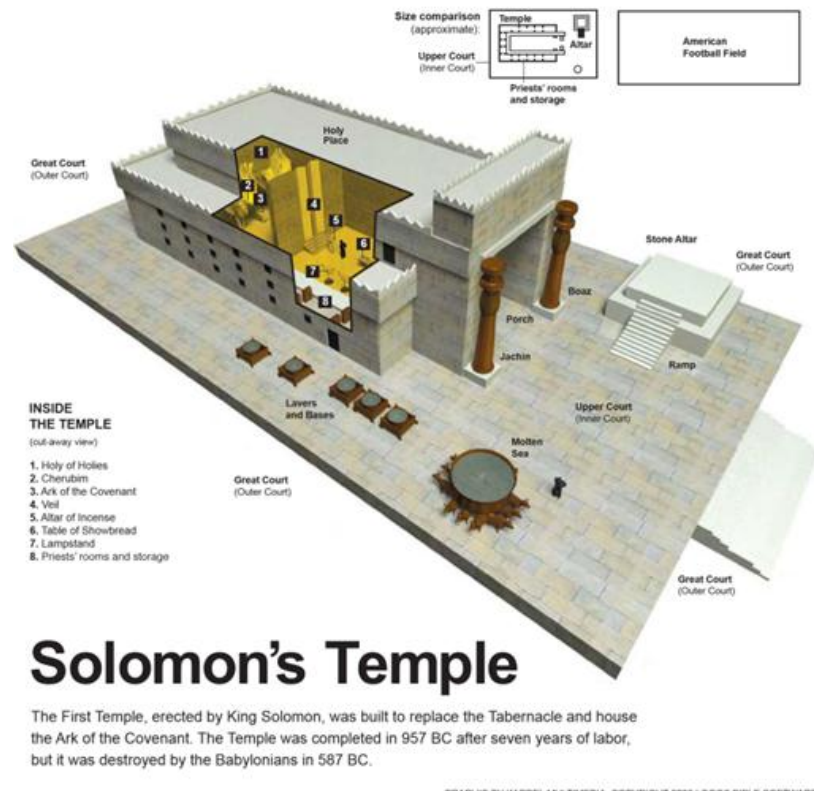

Gambar 2. Ilustrasi Bait Allah Salomogoogle, "Solomon's Temple,” n.d., https://images.search.yahoo.com/search/images;

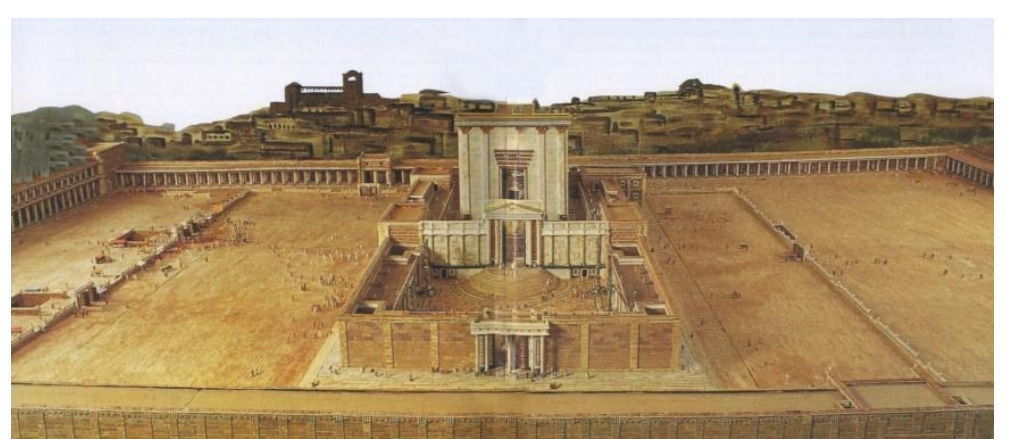

Gambar 3. Ilustrasi Bait Allah Keduagoogle, "The Second Temple of Jerusalem," ., https://images.search.yahoo.com/search/images; 


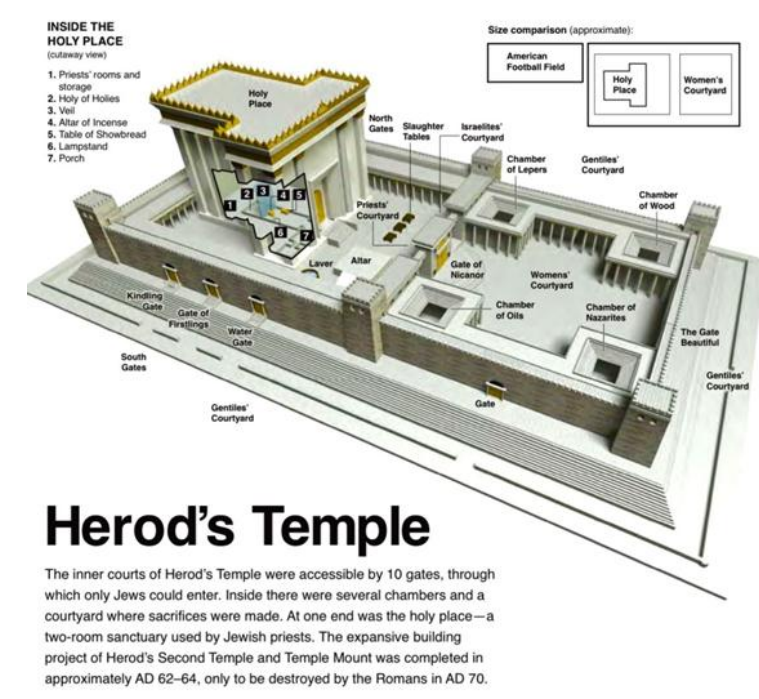

Gambar 4. Ilustrasi Bait Allah Herodes.google, "Herod's Temple," n.d., https://images.search.yahoo.com/search/images

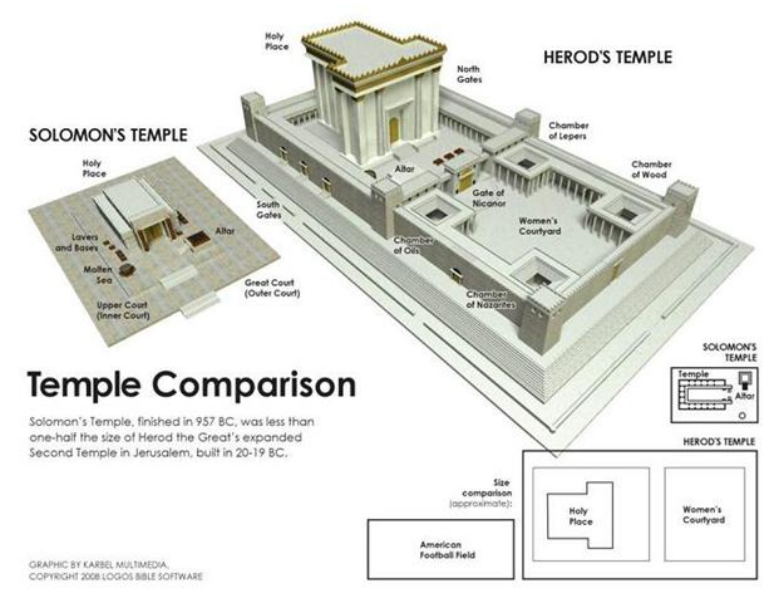

Gambar 5. Perbandingan Bait Allah Salomo dengan Bait Allah Herodes.google, "Temple Comparison," n.d., https://images.search.yahoo.com/search/images

Sumber utama informasi tentang Bait Allah Herodes ditemukan dari catatan Josephus, seorang cendikiawan Yahudi yang mengamati dan mencatat pemberontakan Yahudi melawan Romawi, yang puncaknya terjadi pada penghancuran total Bait Allah kedua pada tahun $70 \mathrm{M}$ (Conner, 1988, p. 214).

\section{Makna Teologis Kemah Suci dan Bait Allah}

Dari uraian tentang Kemah Suci dan Bait Allah di atas, dapat diperoleh makna teologis dari keduanya sebagaimana diuraikan dibwah ini.

Makna teologis Kemah Suci adalah sebagai lambang atau gambaran Yesus Kristus ketika berada di bumi ini. Kemah Suci sebenarnya adalah sebuah Tabernakel atau tempat kudus di mana Allah berdiam oleh Roh Allah. Sebagaimana Musa diminta untuk meninggalkan bangsa Israel dan naik ke gunung (Kel. 24:18) untuk memperoleh 
penglihatan yaitu "melihat" pola yang menjadi desain dasar bagi Musa untuk membangun tempat kediaman Allah, sebuah kemah di antara umat Allah. Demikian pula setiap orang percaya harus menanggapi undangan Allah dengan pengudusan untuk memisahkan diri dari "orang-orang di negeri ini," dan mendaki "gunung spiritualitas" untuk mendapatkan visi dari Allah tentang Yesus Kristus, yang melalui Kristus juga orang percaya harus membangun "kemah" untuk menjadi tempat kediaman Allah di antara manusia (Lihat 1 Kor. 3:16) (Frey, n.d., p. 3).

Demikian juga Bait Allah. Makna teologis Bait Allah bagi orang Kristen sangat penting, dalam arti bahwa korban penebusan Yesus hanya dapat dipahami sepenuhnya dalam konteks sistem korban di Bait Allah seperti yang diuraikan dalam Alkitab Ibrani (PL). Kesan paling jelas dan berkesan tentang Bait yang dialami dalam Kekristenan berkaitan dengan kurban penebusan Yesus, yang membentuk dasar dari perumpamaan Yesus sebagai anak sulung tanpa cela yang dikorbankan, sekali dan untuk selamanya, untuk menebus dosa umat-Nya. Teologi ini dapat ditemukan paling jelas dan paling luas dalam surat Ibrani, yang secara tradisional dikaitkan dengan kepenulisan Paulus, khususnya bab 7- 10 (Lundquist, 2008, p. 152). Bait Allah ini juga merupakan gambaran dari Bait Allah surgawi yang menjadi tempat kediaman Allah selama-lamanya (Conner, 1988, p. 2).

\section{Kehidupan Rohani Kristen}

Kehidupan rohani orang Kristen memiliki keberpusatan pada Yesus Kristus. Sebagai orang yang telah diubahkan secara rohani, orang Kristen harus memiliki tujuan untuk melakukan kehendak Allah, senantiasa beribadat kepada-Nya, kuat dalam menghadapi segala sesuatu yang terjadi dan melayani sesama dengan sikap hati yang benar, ramah dan lemah lembut (1 Timotius 6:11). Dasar dari semua ini adalah iman dan kepercayaan kepada Yesus Kristus. Hanya melalui iman kepada Yesus seseorang dapat mengantungkan diri sepenuhnya kepada Allah serta memiliki pengenalan akan kehendak Tuhan (Arifianto, 2020b).

Seorang Kristen adalah orang yang dipenuhi dengan Roh Kudus dan hidup dalam pimpinan oleh Roh Kudus. Pertumbuhan rohani akan membawanya serupa karakter dan sifat Yesus, yang menjadi nilai penting untuk terus menjadi berkat. Seorang Kristen yang memiliki kehidupan rohani yang baik akan senantiasa dalam proses menjadi manusia baru, yang akan terus menerus diperbaharui agar dapat memperoleh pengetahuan yang benar menurut gambar dan rancangan Tuhan (Hadiwijono, 1992, p. 26). Implikasinya akan membawa kedewasaan rohani orang Kristen tersebut yang dapat diterapkan dalam kehidupan agar selalu berpegang teguh dan erat kepada kebenaran dan terus bertumbuh di dalam segala hal ke arah Dia, Kristus, yang adalah Kepala (Efesus 4:15) (Tong, 2013, p. 54).

\section{Implementasi Makna Teologis Kemah Suci Dan Bait Allah Bagi Kerohanian Kristen}

Semua 'Rumah Allah' mulai dari Kemah Suci Musa, Kemah Suci Daud, Bait Allah Salomo dan Bait Allah Yehezkiel merupakan hasil dari pola Ilahi atau rancangan Tuhan 
sendiri. Tuhan memberikan pola khusus untuk pembangunan 'rumah-Nya' karena Kemah atau Bait Suci duniawi hanyalah bayangan Bait Suci surgawi di bumi. Tatanan surgawi adalah prototipe, asli, nyata, abadi, sedangkan yang di bumi adalah bayangan yang sifatnya sementara. Kitab Suci secara pasti berbicara tentang Bait Suci surgawi (Yesaya 6: 1; 66: 6; Wahyu 11:19; 14: 15-17;15: 5) (Conner, 1988, p. 24).

Kemah Suci dan semua bagian-bagiannya, perlengkapannya hingga sistem dan ritual-ritual peribahan di dalamnya merupakan gambaran detail dari Kristus itu sendiri. Empat jenis tirai penutup Kemah Suci merupakan gambaran akan karya penyelamatan dan penebusan yang dilakukan oleh Mesias (Jong, 2003, pp. 108-109).

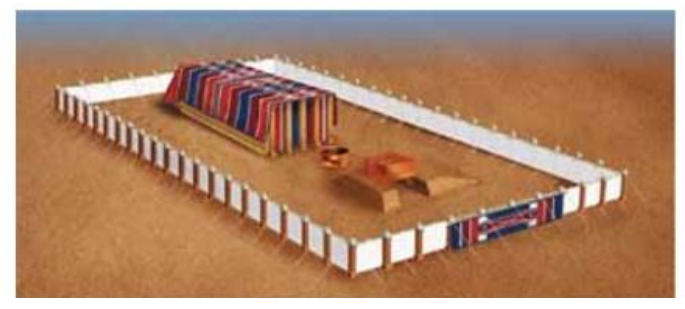

1. Penutup pertama Kemah Suci dibuat dengan tenunan tirai dengan desain artistik kerub dengan menggunakan benang biru, ungu, dan kirmizi serta linen halus (Kel. 26:1). Ini mengungkapkan bahwa Mesias akan datang melalui kain biru, ungu, dan kain kirmizi dan kain linen halus dan dengan demikian menyelamatkan semua orang yang percaya kepada-Nya dari dosa dan hukuman mereka.

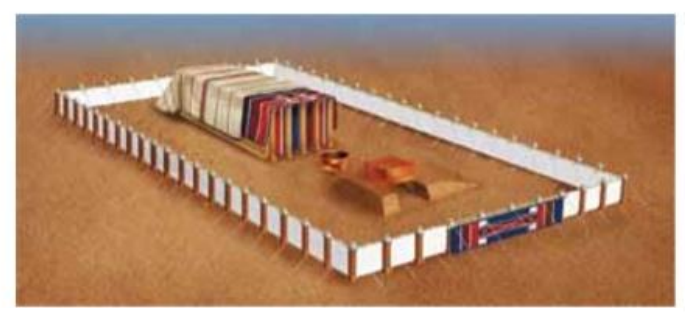

2. Penutup kedua Kemah Suci itu terbuat dari bulu kambing (Kel. 26:7). Ini memberitahu kita bahwa Mesias yang akan datang akan membenarkan umat manusia dengan membebaskan mereka dari dosa-dosa mereka dan hukuman atas dosa-dosa ini.

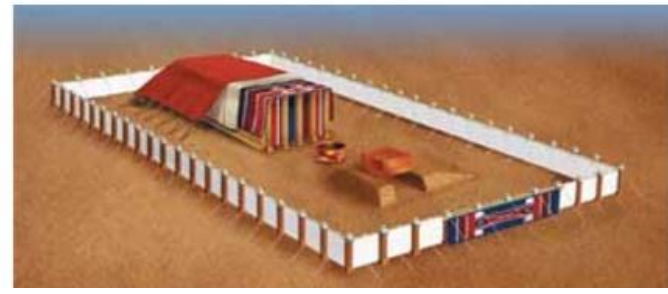

3. Penutup ketiga Kemah Suci itu terbuat dari kulit domba jantan yang diwarnai merah (Kel. 26:14). Ini menyatakan bahwa Mesias akan datang ke dunia ini, menanggung dosa dunia dengan dibaptis, disalibkan, dan dengan demikian menjadi korban persembahan untuk dosa umat-Nya.

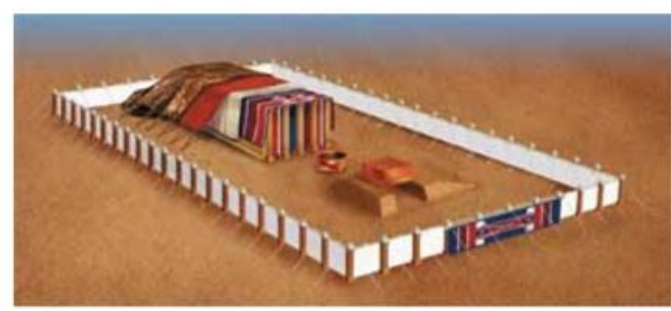

4. Penutup keempat Kemah Suci itu terbuat dari kulit lumba-lumba (Kel. 26:14). Kulit lumba-lumba menunjukkan kepada kita potret Yesus Kristus yang merendahkan diri-Nya sampai ke tingkat manusia untuk menyelamatkan kita dari dosa dunia.

Gambar 6. Ilustrasi makna penutup Kemah Suci (Jong, 2003, p. iii).

Tabel berikut ini akan menunjukkan makna Kemah Suci sebagai simbol terhadap pelayanan Kristus. 
Table 1. Perbandingan Kemah Suci bagi Orang Israel dan Tuhan Yesus bagi Orang Kristen (Publishing, 2008, p. 32)

\begin{tabular}{|l|l|}
\hline $\begin{array}{l}\text { Orang Israel Berkomunikasi dengan Allah } \\
\text { melalui Kemah Suci }\end{array}$ & $\begin{array}{l}\text { Orang Kristen Berinteraksi dengan } \\
\text { Allah melalui Yesus }\end{array}$ \\
\hline Altar perunggu untuk korban & Pengorbanan Kristus \\
\hline Bejana perunggu untuk mencuci & Pembersihan melalui pengakuan dosa \\
\hline Kaki dian & Tercerahkan oleh Roh Kudus \\
\hline Meja roti Persembahan & Beroleh makan dari Firman Yang Hidup \\
\hline Altar dupa & Doa, komunikasi, syafaat \\
\hline Melalui tabir menuju Tempat Maha Kudus & $\begin{array}{l}\text { Memasuki hadirat Tuhan dengan berani } \\
\text { melalui Kristus }\end{array}$ \\
\hline Imam dan pakaian & Layanan kepada Tuhan dan orang lain \\
\hline
\end{tabular}

Kebenaran termanifestasi di Kemah Suci. Pilar-pilar pintu Kemah Suci semuanya dilapisi dengan emas. Ini menunjukkan bahwa tidak ada satupun di dalam Kemah Suci yang memiliki jejak manusia. Segala sesuatu di dalam Kemah Suci dilapisi dengan emas; pilar pintunya dilapisi dengan emas, dan penutup di atas pilar juga dilapisi dengan emas. Namun, alas tiangnya terbuat dari perunggu. Ini merupakan suatu gambaran tentang dosa dan noda manusia, karena dosa semua manusia terikat ke neraka. Ketika ada kesadaran di dalam hati bahwa setiap manusia terikat ke neraka, dan ketika percaya pada kebenaran bahwa Tuhan telah menyelamatkan setiap orang Kristen dengan memberikan anugerah keselamatan digenapi dengan karya Kristus yang diwujudkan dalam kain biru, ungu, dan kain kirmizi, maka semua orang Kristen yang percaya dapat masuk dan tinggal di Tempat Kudus.

Orang Kristen percaya bahwa Tuhan datang ke dunia ini. Tuhan yang jauh lebih berharga dari pada manusia, menanggung dosa-dosa manusia dengan dibaptis. Tuhan menumpahkan darah-Nya dan mati di kayu Salib. Dengan melakukan itu Tuhan telah membasuh semua dosa orang Kristen yang percaya dan menyelamatkan setiap orang Kristen yang percaya dari kutukan dosa. Dengan menyelamatkan melalui benang biru, ungu, dan kain kirmizi, Tuhan telah menjadikan setiap orang Kristen yang percaya menjadi benar. Seorang Kristen harus benar-benar percaya di dalam hati karena hanya yang percaya pada kebenaran ini yang dapat menjadi umat Tuhan dan turut dalam pekerjaan Tuhan. Menerima kebenaran ini hanya sebagai salah satu pemikiran manusia bukanlah iman yang benar (Jong, 2003, p. 32).

Soket tiang pintu Kemah Suci terbuat dari perunggu. Tetapi soket perunggu hanya digunakan untuk lima pilar pintu Kemah Suci; sebaliknya, pilar untuk tabir Ruang Maha kudus tidak memiliki soket perunggu, tetapi keempat soket dari pilar ini semuanya terbuat dari perak. Dalam Alkitab, perak menunjukkan pemberian dan anugrah Tuhan, sedangkan emas menunjukkan iman sejati orang yang percaya di pusat hati. Perunggu, di sisi lain, menunjukkan penghakiman atas dosa. Masing-masing orang akan dihakimi karena dosa di hadapan Allah dan manusia.

Ketika Tuhan datang ke bumi ini, Tuhan datang sebagai manusia. Tuhan menanggung segala dosa orang percaya ke atas tubuh-Nya dengan dibaptis. Tuhan menanggung semua penghukuman atas dosa-dosa orang percaya dengan mati di kayu Salib, dan telah menjadi Juruselamat yang sempurna melalui kebangkitan dari antara 
orang mati. Ketika seorang Kristen percaya, keselamatan di dalam Yesus Kristus yang telah Tuhan rencanakan bahkan sebelum penciptaan akan diperoleh sepenuhnya. Rencana Tuhan untuk menjadikan orang-orang Kristen yang percaya menjadi umat Tuhan terpenuhi ketika setiap orang Kristen percaya pada rencana ini. Percaya di dalam hati akan membuat keselamatan sejati muncul. Keselamatan tidak dicapai dengan pikiran kedagingan. Keselamatan tidak muncul melalui doktrin teologis apapun. Sebaliknya, keselamatan terjadi hanya dengan iman dalam kebenaran (Jong, 2003, pp. 78-79).

Di dalam roh, Daud melihat Bait Suci surgawi, sama seperti Musa melihat Kemah Suci surgawi. Semua tatanan surgawi itu sempurna dan lengkap. Semua pola sesuai dengan rancangan Ilahi, Tuhan, Arsitek alam semesta. Oleh karena itu, Bait Suci duniawi sebagai tempat kediaman Allah di bumi harus sesuai dengan pola surgawi (Yesaya 57:15). Bait Suci di bumi akan menjadi tempat tinggal duniawi Allah di mana Allah dapat tinggal di antara umat-Nya oleh Roh-Nya. Di sini Allah dapat mengungkapkan kemuliaan-Nya, berbicara dengan suara kepada Imam Besar yang ditunjuk dan diurapiNya di atas tanah penebusan. Ini menunjuk pada Kristus yang adalah Bait Allah secara jasmani di bumi (Yohanes 2: 19-21). Allah ada di dalam Kristus sebagai Bait Allah. Roh Allah, kemuliaan Allah, dan suara Allah didengar di dalam dan melalui Kristus. Kristus adalah kediaman Allah dimanapun Kristus berjalan. Kristus tidak berdosa dan sempurna. Kristus adalah "Manusia Pola Ilahi". Oleh karena itu, materi Bait Suci duniawi Allah yang merupakan nubuatan Kristus harus sesuai dengan pola Ilahi.

Hal yang sama berlaku untuk Gereja sebagai Tubuh Kristus. Gereja sebagai bait Perjanjian Baru Tuhan, harus dibangun sesuai dengan pola yang ditetapkan dalam Firman Tuhan. Tuhan hanya dapat memberi berkat di tengah-tengah umat-Nya berdasarkan apa yang seluruhnya adalah milik-Nya. Tuhan hanya dapat tinggal di antara umat-Nya dalam kegenapan kemuliaan karena semuanya diukur dengan ukuran Ilahi oleh Roh. Tuhan hanya dapat memeteraikan dengan api kemuliaan-Nya semua yang sesuai dengan pola surgawi. Kristus dan Gereja adalah satu dalam pikiran Bapa. Semua ini ada dalam tulisan-tulisan Kitab Suci, yang diberikan oleh Roh. Ini adalah pelayanan Gereja dan kepemimpinannya untuk dibangun sesuai dengan pola Tuhan (1 Timotius 3:16; 1 Petrus 1: 11-12; 2 Petrus 1: 20-21).

Paulus sebagai ahli bangunan yang bijaksana, menerima pola dan aturan Ilahi untuk Gereja Perjanjian Baru, Bait Allah, dan menasihati semua pembangun lainnya untuk "memperhatikan bagaimana mereka membangun" (1 Korintus 3: 9-17; 6: 19; Efesus 2: 20-22). Jika Allah secara khusus memberikan pola materi tentang Bait Suci yang dibangun menurut pola Ilahi, Allah juga akan memberikan perhatian khusus baik kepada Kristus sebagai Kepala maupun kepada Gereja sebagai tubuh Kristus, yang bersama-sama menjadi Bait Allah. Pelayanan melalui dedikasi penuh sebagai pelajaran untuk Gereja. Gereja yang adalah umat Allah sekarang adalah Bait atau Kemah Allah. Roh Kudus adalah kemuliaan shekinah di tengah-tengah umat Allah. Nama Tuhan, Hukum Tuhan, Kehadiran Tuhan dan Kemuliaan Tuhan tinggal di Gereja Tuhan. Di dalam Gerejalah orang Kristen membuat pengorbanan rohani kepada Tuhan dalam 
imamat Perjanjian Baru, imamat kerajaan. Tuhan ingin agar orang Kristen memelihara Bait Suci yang murni dan kudus untuk tempat tinggal Tuhan (1 Korintus 3:16; 1 Timotius 3: 15-16; 1 Petrus 2: 5-9) (Conner, 1988, p. 25).

Pewahyuan dan pola yang Tuhan berikan untuk pembangunan Kemah Suci, Bait Allah hingga Gereja Tuhan dari masa PB hingga saat ini, memiliki pola dan hubungan yang sangat identik. Tabel berikut ini akan memberikan gambaran hubungan yang ada antara Kemah Suci, Bait Allah dan Gereja Tuhan saat ini.

Tabel 2. Hubungan Kemah Suci, Bait Allah dan Gereja Kristus(Conner, 1988, p. 25)

\begin{tabular}{|c|c|}
\hline Kemah Suci Allah & Bait Suci Allah \\
\hline Pewahyuan dan Pola & Pewahyuan dan Pola \\
\hline Diberikan kepada Musa & Diberikan kepada Daud \\
\hline Diberikan kepada Harun & Diberikan kepada Salomo \\
\hline Imam Besar & Raja Israel \\
\hline Suku Lewi & Gereja Yehuda \\
\hline \multicolumn{2}{|c|}{ Pewahyuan dan Pola } \\
\hline Diberikan kepada Kristus \\
\hline Diberikan kepada para pelayan \\
\hline Raja dan Imam dari jalur Melkisedek \\
Kristus dari suku Yehuda \\
\hline
\end{tabular}

\section{Kesimpulan}

Uraian di atas menunjukkan bahwa Allah tidak hanya menduplikasi Kemah Suci Musa ketika membangun Bait Suci Salomo, tetapi sebenarnya memperkuat semua aspek yang ada di Kemah Suci dengan kebenaran Ilahi yang lebih besar, lebih kaya, lebih lengkap dan lebih signifikan di dalam Bait Suci tersebut. Kemah Suci Allah berbicara tentang Kristus dalam perjalanan, pelayanan dan kemuliaan-Nya di bumi. Bait Suci Allah berbicara tentang Kristus dalam pelayanan dan kemuliaan surgawi-Nya.

Berdasarkan karya penebusan Kristus yang digambarkan dengan jelas dan detail melalui Kemah Suci maupun Bait Suci, setidaknya ada empat implikasi makna teologis penting dari keduanya bagi kehidupan rohani (religious) orang Kristen masa kini. Pertama, Kemah Suci atau Bait Allah menunjukkan pola penyembahan yang ditetapkan oleh Allah untuk masuk kedalam hadirat-Nya melalui Yesus Kristus (Ibrani 10: 19-25). Oleh sebab itu, setiap orang harus percaya dan menerima Yesus sebagai Tuhan dan Juruselamat untuk dapat berkenan, masuk dan menyembah Allah dalam hadirat-Nya Yang Maha Kudus. Kedua, orang Kristen yang percaya saat ini adalah "Rumah Allah" atau Bait/Kemah Suci bagi Roh Allah berdiam (1 Korintus 6:19). Oleh sebab itu, setiap orang Kristen harus hidup dalam kekudusan, berubah oleh pembaharuan akal budi dan tidak menjadi serupa dengan dunia (Roma 12:2). Ketiga, sebagaimana hadirat Kudus Allah ada di antara Israel melalui "Rumah-Nya" untuk menuntun mereka (Keluaran 40: 3438), demikian juga bagi orang Kristen, umat Allah masa kini, Allah hadir ke dunia melalui orang Kristen dan senantiasa menuntun orang Kristen dalam setiap perjalanan kehidupannya. Keempat, sebagai orang percaya, setiap orang Kristen adalah bagian dari imamat yang rajani (1 Petrus 2: 5, 9). Dengan demikian, orang Kristen harus 
mempersembahkan dirinya bagi Allah (Roma 12:1) dan menjadi saksi-Nya di dunia (Matius 28:18-20).

\section{Rujukan}

Arifianto, Y. A. (2020a). Deskripsi Sejarah Konflik Horizontal Orang Yahudi dan Samaria. Pasca : Jurnal Teologi Dan Pendidikan Agama Kristen : Jurnal Teologi Dan Pendidikan Agama Kristen, 16(1), 33-39. https://doi.org/10.46494/psc.v16i1.73

Arifianto, Y. A. (2020b). Kajian Biblikal tentang Manusia Rohani dan Manusia Duniawi. Jurnal Teruna Bhakti, 3(1), 12-24.

Arifianto, Y. A., \& Santo, J. C. (2020). Studi Deskriptif Teologis Pembangunan Bait Suci Orang Samaria di Gunung Gerizim. Jurnal Teologi Berita Hidup, 3(1), 66-80.

Beale, G. K. (2004). The temple and the church's mission: a biblical theology of the dwelling place of God. In New studies in biblical theology.

Bloch-Smith, E. (2020). Solomon's Temple: In Sacred Time, Sacred Place. https://doi.org/10.5325/j.ctv1bxh3xp.10

Bowo, T. (2020). Fungsi Bait Suci Bagi Umat Pilihan Allah. Sanctum Domine: Jurnal Teologi. https://doi.org/10.46495/sdjt.v8i2.50

Conner, K. J. (1988). The Temple of Solomon: The Glory of God as Displayed Trough the Temple. City Bible Publishing.

Flanders, Jr, Henry Jackson \& Cresson, B. C. (1973). Introduction To The Bible. The Ronald Press Company.

Frey, A. (n.d.). Notes on The Tabernacle.

Garber, P. L., \& Parrot, A. (1958). The Temple of Jerusalem. Journal of Biblical Literature. https://doi.org/10.2307/3264618

google. (n.d.-a). Herod's Temple.

https://images.search.yahoo.com/search/images;_ylt=Awr9DWvXczJgzWYAJjKJ zbkF;_ylu=c2VjA3NlYXJjaARzbGsDYnV0dG9u;_ylc=X1MDOTYwNjI4NTcEX3IDM gRhY3RuA2NsawRjc3JjcHZpZANFdWpzSkRFd0xqSXJXc0JoWHpTOXhnYWdNVE UwTGdBQUFBRFIIRGp0BGZyA21jYWZIZQRmcjIDc2EtZ3AEZ3ByaWQDTTZz

google. (n.d.-b). Solomon's Temple.

https://images.search.yahoo.com/search/images;_ylt=Awr9FqwtbzJgXx8A9syJ zbkF;_ylu=c2VjA3NIYXJjaARzbGsDYnV0dG9u;_ylc=X1MDOTYwNjI4NTcEX3IDM gRhY3RuA2NsawRjc3JjcHZpZANIMDI3U1RFd0xqSXJXc0JoWHpTOXhnUIZNVEU wTGdBQUFBQ1E4NWhGBGZyA21jYWZIZQRmcjIDc2EtZ3AEZ3ByaWQDXzA0

google. (n.d.-c). Temple Comparison.

https://images.search.yahoo.com/search/images;_ylt=Awr9DWvXczJgzWYAJjKJ zbkF;_ylu=c2VjA3NIYXJjaARzbGsDYnV0dG9u;_ylc=X1MDOTYwNjI4NTcEX3IDM gRhY3RuA2NsawRjc3JjcHZpZANFdWpzSkRFd0xqSXJXc0JoWHpTOXhnYWdNVE UwTGdBQUFBRFIIRGp0BGZyA21jYWZIZQRmcjIDc2EtZ3AEZ3ByaWQDTTZz

google. (n.d.-d). The Second Temple of Jerusalem.

https://images.search.yahoo.com/search/images;_ylt=Awr9DWvXczJgzWYAJjKJ zbkF;_ylu=c2VjA3NIYXJjaARzbGsDYnV0dG9u;_ylc=X1MDOTYwNjI4NTcEX3IDM gRhY3RuA2NsawRjc3JjcHZpZANFdWpzSkRFd0xqSXJXc0JoWHpTOXhnYWdNVE UwTGdBQUFBRFIIRGp0BGZyA21jYWZIZQRmcjIDc2EtZ3AEZ3ByaWQDTTZz

Hadiwijono, H. (1992). Iman Kristen. BPK Gunung Mulia.

Hill, Andrew \& Walton, J. (2008). Survey Perjanjian Lama. Penerbit Gandum Mas.

Hinckley, R. (2013). Adam, Aaron, and the Garden Sanctuary. Reformation. 
Homan, M. M. (2007). The Tabernacle and the Temple in Ancient Israel. Religion Compass. https://doi.org/10.1111/j.1749-8171.2006.00006.x

Jong, P. C. (2003). The Tabernacle: A Detailed Portrait of Jesus Christ (II). Hephzibah Publishing House.

Joseph, M., \& Joseph, M. (2020). Tabernacles. In Judaism as Creed and Life. https://doi.org/10.4324/9781003023371-23

Killebrew, A. E. (2015). Jerusalem: Capital city created in stone and in imagination. In The Cambridge World History: Volume III: Early Cities in Comparative Perspective, 4000 BCE-1200 CE. https://doi.org/10.1017/CH09781139035606.026

Loader, W. (2008). A Kingdom of Priests: Ancestry and Merit in Ancient Judaism. Journal for the Study of Judaism. https://doi.org/10.1163/157006308x375852

Lundquist, J. M. (2008). The Temple of Jerusalem: Past, Present and Future. Praeger Publisher.

Mangean, A. (2019). Pendekatan Historis Kristis Terhadap Bilangan 3 dan 4 tentang Tanggung Jawab Pendeta. BIA': Jurnal Teologi Dan Pendidikan Kristen Kontekstual. https://doi.org/10.34307/b.v2i2.133

O'Collins, Gerald \& Keenan Jones, M. (2010). Jesus Our Priest: A Christian Approach to the Priesthood of Christ. Oxford University Press.

Publishing, R. (2008). Rose Guide to the Tabernacle. Rose Publishing, Inc.

Snyder, H. G. (2011). Early christianity. In The Cambridge Companion to Ancient Mediterranean Religions. https://doi.org/10.1017/CC09781139047784.012

Sprinkle, J. (2000). The Rationale of the Laws of Clean and Unclean in the Old Testament. Journal of the Evangelical Theological Society.

Tong, S. (2013). From Faith To Faith, Dari Iman Kepada Iman. Momentum.

Wasserman, J. (2011). The Temple of Solomon: From Ancient Israel to Secret Societies. Inner Traditions.

Zaluchu, S. E. (2020). Strategi Penelitian Kualitatif dan Kuantitatif Di Dalam Penelitian Agama. Evangelikal: Jurnal Teologi Injili Dan Pembinaan Warga Jemaat, 4(1), 2838. https://doi.org/10.46445/ejti.v4i1.167

Zaluchu, S. E. (2021). Metode Penelitian di dalam Manuskrip Jurnal Ilmiah Keagamaan. Jurnal Teologi Berita Hidup, 3(2). https://doi.org/10.38189/jtbh.v3i2.93

י, אלוני,., \& Aloni, J. (1983). The Place of Worship and the Place of Slaughter According to Leviticus 17:3-9 / מקום הפולחן ומקום השחיטה לפי ויקרא יז ג-ט Shaton: An Annual for

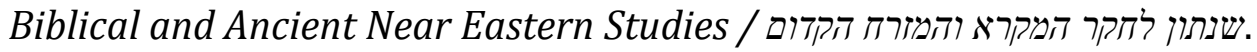

